\title{
The Effect of Peat and Vermicompost Cavitation Products on the Soil Biological Activity
}

\author{
Vilhelmine Steinberga ${ }^{1}$, Laila Dubova ${ }^{1 *}$, Ina Alsina ${ }^{1}$, Galina Gmizo ${ }^{1}$ \\ Solveiga Malecka ${ }^{2}$ \\ ${ }^{1}$ Institute of Soil and Plant Science, Latvia University of Agriculture, \\ Liela 2, Jelgava LV-3001, Latvia \\ ${ }^{2}$ State Stende Cereals Breeding Institute, \\ „Dižzemes”, Dižstende, Lībagi parish, Talsi County LV-3258, Latvia
}

\begin{abstract}
Commercial products with humic substances have often been recommended for plant growth stimulation and yield improvement. The aim of this study was to clarify the effects of two products, containing cavited peat and vermicompost respectively on the soil biological activity. Vegetation experiments with garden cress and cucumbers were arranged in pots with a peat substratum in the greenhouses of the Latvia University of Agriculture. The plants were treated with the preparations once a month. The first treatment was done at sowing. Dose of 20, 2, $0.2 \mathrm{~mL}$ per $\mathrm{m}^{2}$ during each treatment time were used. A control variant was without peat or vermicompost preparation. Field experiments with onions were carried out in the organic farming experimental field of the Latvia State Institute of Cereal Breeding. Plant growth and soil (substratum) biological activity (respiration and enzymatic activity) were tested. Plant growth and response to the different preparations depended on the plant species and its development stage. The effect of preparations decreases during plant development. The impact of peat or vermicompost preparation on soil biological activity depended not only on the concentration of preparation, but was influenced by the soil or growth media type. The decrease of onion yield in field conditions as a result of preparations was observed.
\end{abstract}

Key words: enzymes, humic substances, soil respiration.

\section{Introduction}

Different organic additives are often used to improve soil quality. As Kennedy et al. indicated (2004), soil quality is the capacity of a soil to function within ecosystem boundaries to sustain biological productivity, maintain environmental quality, and promote plant and animal health. A high quality soil is biologically active and contains a balanced population of microorganisms.

The organic soil additives such as vermicompost, municipal waste compost or garden wastes compost contain relevant macro, micro nutrients and biologically active substances for plant growth and development (Trevisan, Francioso, Quaggiotti \& Nardi, 2010; Warman \& AngLopez, 2010). In addition to peat, manure or composts, nowadays farmers may use both the various commercial products extracted from peat or other organic materials and chemically modified ones. Chemical reactions (hydrolysis, oxidation, reduction, methylation, alkyl compounds detachment) were applied to modify the structure of humic substances (HS) isolated from vermicompost. Structural and conformational changes of these humic derivatives often exhibited a large bioactivity compared to original humic substances (Trevisan, Francioso, Quaggiotti \& Nardi, 2010; Dobbss et al., 2012).

The mechanisms of how humic substances can influence plant growth are not clear. The effects of these products on soil microorganisms are also still being analysed because soil biological activity can significantly change soil quality. Soil microbiological activity depends on plant, microbe, and soil organic matter interactions. Plants are able to influence the composition and activity of the microbial community around their root systems through the selective exudation of specific carbohydrates, carboxylic and amino acids, and these microbial communities can be cultivar-specific (Parmar \& Dardarwal, 1999; Gamaley et al., 2001; Sturz \& Christie, 2003). Studies have shown that humic substances stimulate the germination of various crop species and influence plant root, leaf and shoot growth too. A humic fraction has been observed to stimulate Avena split coleoptiles, the elongation secondary roots of Zea mays and the growth of tomato plants. At the same time some results demonstrated an inhibiting effect on the growth of microorganisms (Fogarty \& Ward,

\footnotetext{
* Corresponding Author's email: 
1970; Canellas, Olivares, Okorokova-Facanha \& Rocha, 2002; Zaller, 2002; Schiavon et al., 2010; Trevisan, Francioso, Quaggiotti \& Nardi, 2010). Different peat extracts may change the activity of enzymes. As indicated by Nawaz and Gunasekaran (1988), peat extract influence on enzymatic activity depends on the type of peat extract. They found out that an autoclaved extract had the most significant effect. The different types of peat extracts can contain various biologically active components. Some authors (Tarnawski, Depta, Grejciun \& Szelepin, 2006) have found phenol acids, derivatives of benzoic acid, cinnamic acid and antioxidant activity in the peat extracts.

Soil biochemical properties were used to diagnose soil biological activity. These properties include both general biochemical parameters of soil respiration intensity, microbial biomass, dehydrogenase activity and the specific biochemical parameters, for example, the activity of hydrolytic enzymes. Soil respiration intensity is an indicator of the activity of different soil organisms (bacteria, fungi, Protozoa) as well as the respiration of plant roots (Brooke, 2001; Bloem et al., 2005; Burns, Nannipieri, Benedetti \& Hopkins, 2005).

The purpose of this study is to evaluate and compare the effect of cavited peat and vermicompost products on soil biological activity.

\section{Materials and Methods}

To evaluate soil biological activity of peat and vermicompost cavitations' products, vegetation and field experiments were carried out during 20112012, and the effects on peat substratum and soil microbiological and enzymatic activity was clarified. The cavitation was done by "Intellectual resources" LTD in Latvia. The peat cavitation product (PCP) contained $\mathrm{N}-25 \mathrm{mg} \mathrm{kg}^{-1}, \mathrm{P}_{2} \mathrm{O}_{5} 10 \mathrm{mg} \mathrm{kg}^{-1}, \mathrm{~K}_{2} \mathrm{O}$ $330 \mathrm{mg} \mathrm{kg}^{-1}$, organic matter $20 \mathrm{~g} \mathrm{~kg}^{-1}, \mathrm{pH} \mathrm{KCl} 8.3$. Vermicompost cavitation product (VCP) contained $\mathrm{N}$ $-190 \mathrm{mg} \mathrm{kg}{ }^{-1}, \mathrm{P}_{2} \mathrm{O}_{5} 100 \mathrm{mg} \mathrm{kg}^{-1}, \mathrm{~K}_{2} \mathrm{O} 2600 \mathrm{mg} \mathrm{kg}$, organic matter was $20 \mathrm{~g} \mathrm{~kg}^{-1}$ and $\mathrm{pH} \mathrm{KCl} 9.6$. The vegetation experiments were placed in the experimental greenhouse of the Latvia University of Agriculture. Plants were grown in $5 \mathrm{~L}$ pots with a commercial peat substratum. The parameters of the commercial substratum according to the producer (Laflora) were the following: $\mathrm{pH} \mathrm{KCl} 5.5 \pm 0.5, \mathrm{~N}$ 100 - $140 \mathrm{mg} \mathrm{L}^{-1}, \mathrm{P}_{2} \mathrm{O}_{5} 110$ - $170 \mathrm{mg} \mathrm{L}^{-1}, \mathrm{~K}_{2} \mathrm{O} 190$ - $290 \mathrm{mg} \mathrm{L}^{-1}$ with $\mathrm{Ca}, \mathrm{Mg}, \mathrm{S}$ and the microelements: $\mathrm{Fe}, \mathrm{Mn}, \mathrm{Mo}, \mathrm{Zn}, \mathrm{Cu}$ and B. Garden cress (Lepidum sativum L.), and cucumber (Cucumis sativus L.) cultivar 'Pioneer' were used as experimental plants. The first treatment with the PCP or VCP was done at sowing and then - once a month. The dose during each treatment was $0.2,2,20 \mathrm{~mL}$ per $\mathrm{m}^{2}$ (acquired concentrations 1, 10, $100 \mathrm{~mL} \mathrm{~L}^{-1}$ respectively). Preparations were diluted in tap water. Control was without peat or vermicompost products. All experiments were done in four replicates.

Field experiments were carried out with onion (Allium cepa L.) cultivar 'Centurion' in the organic farming experimental field of the Latvia State Institute of Cereal Breeding. The experimental field soil - a sandy loam, $\mathrm{pH} \mathrm{KCl} \mathrm{6.7,} \mathrm{organic} \mathrm{matter} 24 \mathrm{~g} \mathrm{~kg}^{-1}$ (determined by oxidizing with potassium bichromate $\left(\mathrm{K}_{2} \mathrm{Cr}_{2} \mathrm{O}_{2}\right), \mathrm{K}_{2} \mathrm{O} 174 \mathrm{mg} \mathrm{kg}^{-1}$ and $\mathrm{P}_{2} \mathrm{O}_{5} 276 \mathrm{mg} \mathrm{kg}^{-1}$ (determined by Egner - Riehm method). Soil analysis was done in Latvia State Institute of Cereal Breeding. Fertilizers and chemical protection against diseases, weeds and pests were not used. The soil was fertilised with green manure (plugged buckwheat). Peat (PCP) and vermicompost extract (VCP) $15 \mathrm{~mL}$ per L was first used during sowing time (bulblets were soaked) and then - twice with one month interval plants were sprayed with preparations in the rate $250 \mathrm{~L} \mathrm{ha}^{-}$ ${ }^{1}$. Soil samples were collected two weeks after the treatment with peat and vermicompost preparations. Soil samples were taken using auger with diameter 2 $\mathrm{cm}$. A composite sample of 15-20 drillings was taken from each plot. The field-moist samples were stored in plastic bags at $4{ }^{\circ} \mathrm{C}$ for soil biological activity analysis. Soil analyses were performed at laboratories of Institute of Soil and Plant Sciences Latvia University of Agriculture. All experiments were done in four replicates. At the end of experiment, the yield of onions was analyzed.

Dehydrogenase (DH) activity assay. Dehydrogenase activity was determined according to the method of Kaimi, Mukaidami \& Tamaki, 2007. The sample was mixed with 2-p-iodo-3nitrophenyl-5-phenyltetrazolium chloride (INT) in a 0. $25 \mathrm{M}$ Tris buffer. The solution was incubated in darkness for 24 hours at $30{ }^{\circ} \mathrm{C}$. After the incubation period, methanol was added to extract the formed iodonitrophenylformazan (INTF). The absorbance of the solution was read at $485 \mathrm{~nm}$ against the methanol blank. The iodonitrophenylformazan content was expressed as $\mu \mathrm{g}^{-1} \mathrm{~h}^{-1}$ of INTF on dry weight.

Fluoresceine diacetate (FDA) hydrolysis intensity assay. The method of Chen, Hoitink, Schmitthenner \& Tuovinen (1998) was followed for FDA determination $\left(\mu \mathrm{g}^{-1} \mathrm{~h}^{-1}\right.$ of hydrolysed FDA on dry weight). The sample was mixed with a $60 \mathrm{mM}$ Phosphate buffer and $0.2 \%$ FDA and incubated at $25^{\circ} \mathrm{C}$ for 30 minutes. The hydrolysis reaction was stopped by the addition of acetone. The absorbance was read spectrophotometrically at $490 \mathrm{~nm}$.

Soil respiration intensity assessment. Respiration intensity was determined by the 
measurement of emitted carbon dioxide with the titration method. $50 \mathrm{~g}$ field moisture soil was placed into $500 \mathrm{~mL}$ sealed jars containing beaker with $5 \mathrm{~mL}$ of $0.1 \mathrm{M} \mathrm{KOH}$ solution and incubated $24 \mathrm{~h}$ in the dark at $30{ }^{\circ} \mathrm{C}$. Then, the $\mathrm{KOH}$ solution was removed and titrated with $0.1 \mathrm{M} \mathrm{HCl}$ to determine the amount of $\mathrm{CO}_{2}$ evolved with the soil microbial respiration (Pell, Stenstrom \& Granhall, 2005).

Statistical analysis. Differences between treatments were tested by one-way or two-way analysis of variance $(A N O V A)$ at significance levels of $\mathrm{P} \leq 0.05$. Correlation coefficients were calculated between respiration intensity and enzymatic activity.

\section{Results and Discussion}

During the vegetation experiments substrate biological activity was analysed. As pointed out in the literature, peat biological activity depends on the decomposition level and can be affected by different kinds of additives (Fogarty \& Ward, 1970). As observed in our experiments, amendment of PCP and VCP changed the respiration intensity of the peat substrate differently. In the vegetation experiments with cucumbers (Fig. 1) at the $70^{\text {th }}$ day PCP at the dose 10 and $100 \mathrm{ml} \mathrm{L}^{-1}$ stimulated soil respiration, but $\mathrm{VCP}$ at the same concentrations decreased respiration in comparison with control.

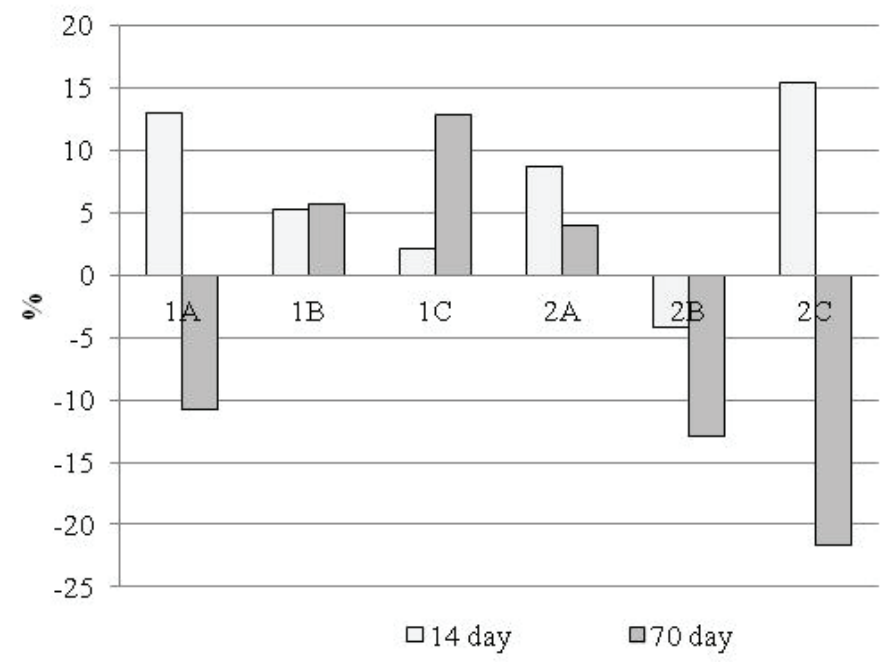

Fig. 1. Variation ( $\%$ from control) of respiration intensity of peat substrate in vegetation experiments with cucumbers: $14^{\text {th }}$ and $70^{\text {th }}$ day after treatment.

1 - PCP: A - $1 \mathrm{~mL} \mathrm{~L}^{-1}, \mathrm{~B}-10 \mathrm{~mL} \mathrm{~L}^{-1}, \mathrm{C}-100 \mathrm{~mL} \mathrm{~L}^{-1}$;

2 VCP: $\mathrm{A}-1 \mathrm{~mL} \mathrm{~L}{ }^{-1}, \mathrm{~B}-10 \mathrm{~mL} \mathrm{~L}^{-1}, \mathrm{C}-100 \mathrm{~mL} \mathrm{~L}^{-1}$.

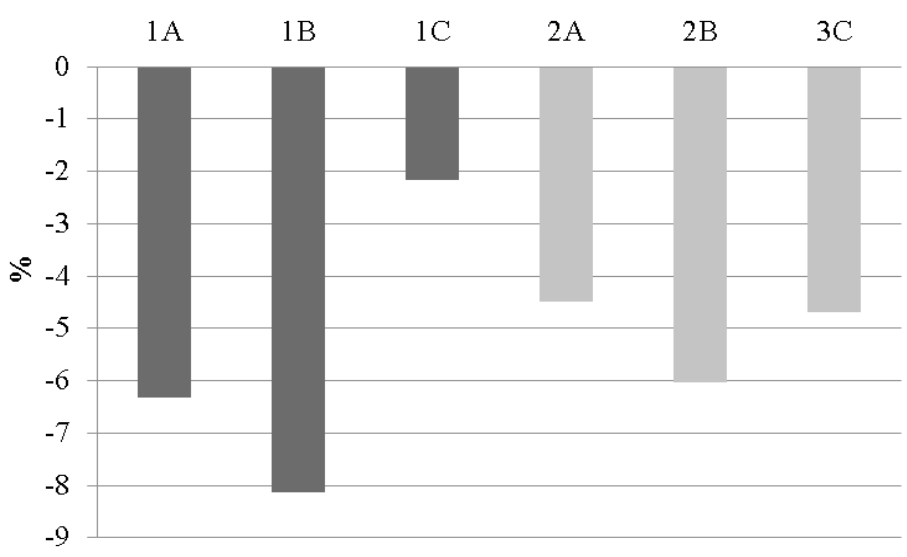

Fig. 2. Variation ( $\%$ from control) of peat substrate respiration intensity at the end of the vegetation experiment with garden cress.

1 - PCP: A - $1 \mathrm{~mL} \mathrm{~L}^{-1}, \mathrm{~B}-10 \mathrm{~mL} \mathrm{~L}^{-1}, \mathrm{C}-100 \mathrm{~mL} \mathrm{~L}^{-1}$;

2 VCP: $\mathrm{A}-1 \mathrm{~mL} \mathrm{~L}{ }^{-1}, \mathrm{~B}-10 \mathrm{~mL} \mathrm{~L}^{-1}, \mathrm{C}-100 \mathrm{~mL} \mathrm{~L}^{-1}$. 


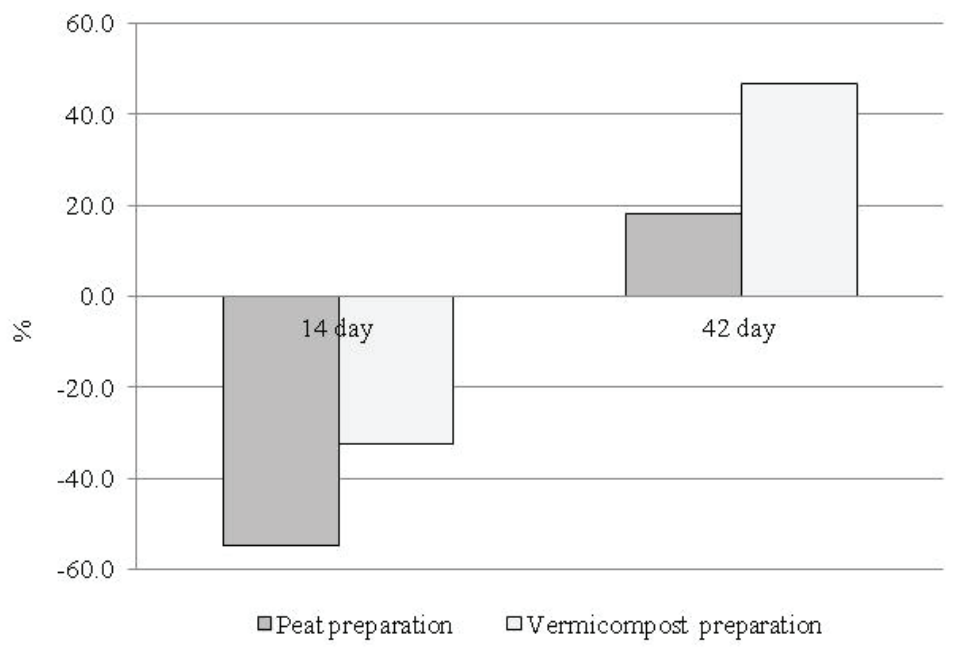

Fig. 3. Variation (\% from control) of soil respiration intensity two weeks after the treatment of onions with peat and vermicompost preparations (dose $10 \mathrm{~mL}$ per L).

In the variants treated with PCP, a higher respiration intensity was observed with a dose of $100 \mathrm{~mL} \mathrm{~L}^{-1}$, but VCP with this dose significantly inhibited respiration intensity. Higher influence on substratum respiration intensity at the later plant growth stages was probably due to an impact of amended preparations on soil microorganisms. In the experiments with a garden cress, in all treatments the decrease of substratum respiration intensity was observed. The highest inhibitory effect was observed with PCP and VCP dose $10 \mathrm{~mL} \mathrm{~L}^{-1}$ (Fig. 2).

In the field experiments with onions at the $14^{\text {th }}$ day after treatment, the soil respiration intensity was significantly lower in the treated variants in comparison to control. The increase of soil respiration during onion vegetation at both treated variants was detected and the variant with VPC after 42 days was significantly higher in comparison with control (Fig. 3).

Substratum and soil respiration intensity depended on plant cultivation method and plant age. In the vegetation pots, a substratum respiration intensity during the plant growth increased, for example, in control with cucumbers on the $14^{\text {th }}$ day of vegetation it was $0.22 \mathrm{mg} \mathrm{CO}_{2} 100 \mathrm{~g}^{-1} \mathrm{~h}^{-1}$, but at the end of vegetation period it was $0.82 \mathrm{mg} \mathrm{CO}_{2} 100 \mathrm{~g}^{-1} \mathrm{~h}^{-1}$. Similar effect was observed with a garden cress when at the end of experiment soil respiration intensity was $0.75 \mathrm{mg} \mathrm{CO}_{2} 100 \mathrm{~g}^{-1} \mathrm{~h}^{-1}$. In the field conditions in the experiments with onions in control variant no changes of soil respiration intensity were observed (on the $14^{\text {th }}$ day 0.196 and on the $42^{\text {nd }}$ day- $0.197 \mathrm{mg}$ $\mathrm{CO}_{2} 100 \mathrm{~g}^{-1} \mathrm{~h}^{-1}$. It should be explained with root density. In the vegetation pots, root density increased significantly due to limited volume of vegetation pot. Similar results were observed also in our previous experiments (Dubova, Alsiņa \& Šteinberga, 2012) and Aon \& Colaneri (2001) who found significant differences in soil microbiological activity in the rows and furrows, season and crop presence. Opposite results were reported by Zydlik \& Zydlik (2013), where in the early summer period, the respiratory activity of soil was distinctly higher, in comparison with the autumn period. It should be explained with different plant species, cultivation conditions and sampling time.

In the experiment with cucumbers grown in peat substratum after 14 days of the treatment the significant increase of $\mathrm{DH}$ activity was observed in variant were PCP dose $1 \mathrm{~mL}$ per $\mathrm{L}$ was used, but negative effect of preparations between the control sample and the variants with $10 \mathrm{~mL}$ per $\mathrm{L}$ peat and vermicompost preparations (Fig. 4). At the end of the experiment the decrease of $\mathrm{DH}$ activity in all variants was observed. The use of PCP dose $100 \mathrm{~mL}$ per L significantly stimulated DH activity of substratum whereas the use of VCP at doses 10 and $100 \mathrm{~mL}$ per $\mathrm{L}$ suppressed the DH activity. Correlation between activity of dehydrogenase and substrate respiration intensity $\left(\mathrm{r}_{0.05 ; 7}=0.75<\mathrm{r}=0.82\right)$ at the end of the experiment was observed.

DH activity significantly decreased $(\mathrm{F}=48.64>$ $\mathrm{F}_{\text {crit }}$ 18.51) in the field experiment with onions where PCP was used (Fig. 6). During the plant vegetation period the soil DH activity increased. Similar results are reported by Zydlik \& Zydlik (2013).

In the same substratum 14 days after treatment, higher FDA hydrolysis intensity as in the control 


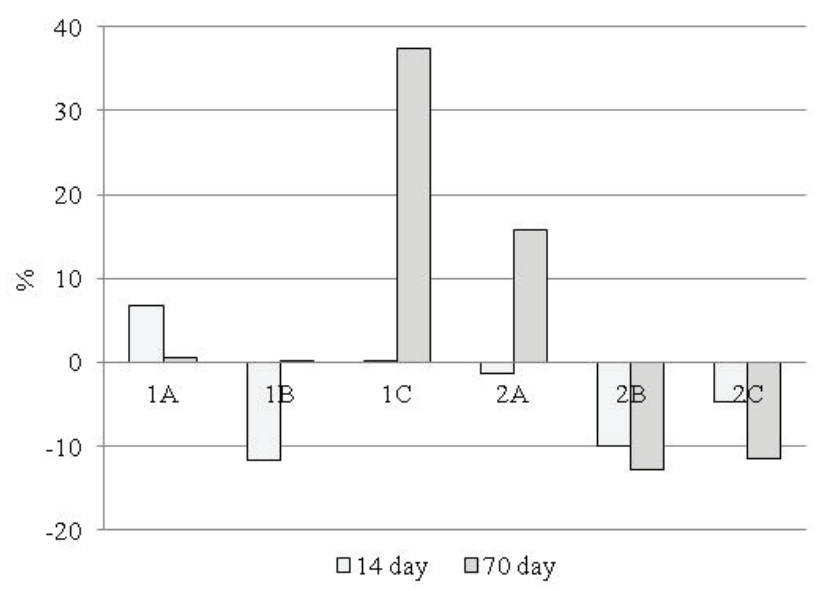

Fig. 4. Variation (\% from control) in peat substrate dehydrogenase activity in the cucumber experiment with added:

1 - peat preparation: $\mathrm{A}-1 \mathrm{~mL} \mathrm{~L}^{-1}, \mathrm{~B}-10 \mathrm{~mL} \mathrm{~L}^{-1}, \mathrm{C}-100 \mathrm{~mL} \mathrm{~L}^{-1}$;

2 vermicompost preparation: $\mathrm{A}-1 \mathrm{~mL} \mathrm{~L}^{-1}, \mathrm{~B}-10 \mathrm{~mL} \mathrm{~L}^{-1}, \mathrm{C}-100 \mathrm{~mL} \mathrm{~L}^{-1}$.

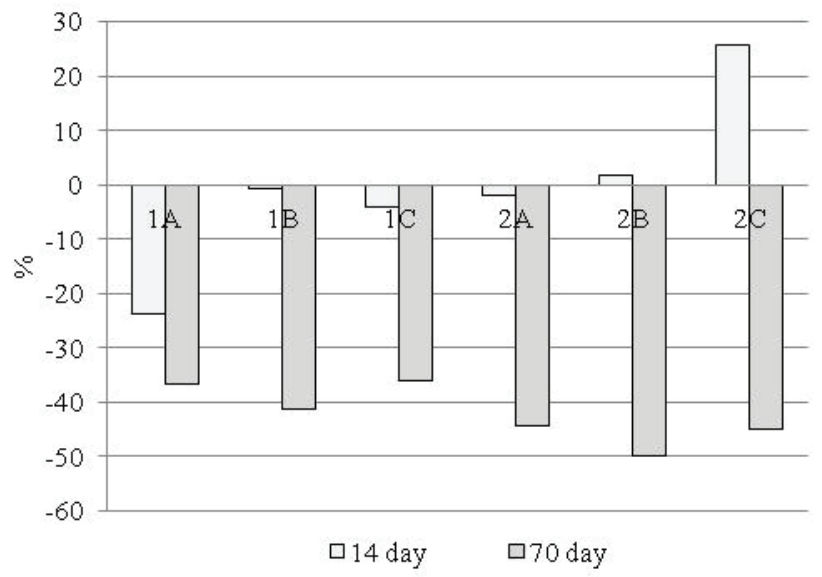

Fig. 5. The effect of added peat preparation (1A, 1B, 1C) and vermicompost preparation (2A, 2B, 2C) on peat substrate FDA hydrolysis activity ( $\%$ from control) in the cucumber experiment: preparation concentration: $\mathrm{A}-1 \mathrm{~mL} \mathrm{~L}{ }^{-1}, \mathrm{~B}-10 \mathrm{~mL} \mathrm{~L}^{-1}, \mathrm{C}-100 \mathrm{~mL} \mathrm{~L}^{-1}$.

variant was found only in the variant treated with VCP (100 mL per L) (Fig. 5) whereas at the end of experiment the decrease of FDA hydrolysis activity in comparison with control was observed in all treated variants. Larger inhibitory effect was observed in variants where VCP was used. Statistic elaboration of data showed no significant effect of preparations, but significant effect of sampling time and plant species. Aon \& Colaneri (2001) reported that FDA hydrolysis activity was influenced by the season and cultivated crop. No significant correlation between soil (substratum) respiration intensity and FDA hydrolysis activity was observed at the end of experiments.
The effect of preparations on plants grown in vegetation pots depended on plant species, preparation and plant developmental stage. Date statistical analyses did not show significant differences between variants, but the tendency that preparations effect decreases during plant development was observed. Thus, on the $14^{\text {th }}$ day of experiment the weight of cucumber plants treated with PCP was $17.2 \%$ higher, but with VCP $12.0 \%$ higher in comparison with control, but on the $36^{\text {th }}$ day the differences between treated variants and control were $6.2 \%$ and $-5.1 \%$ respectively.

The use of cavited peat and vermicompost preparations for onion growing in field conditions 


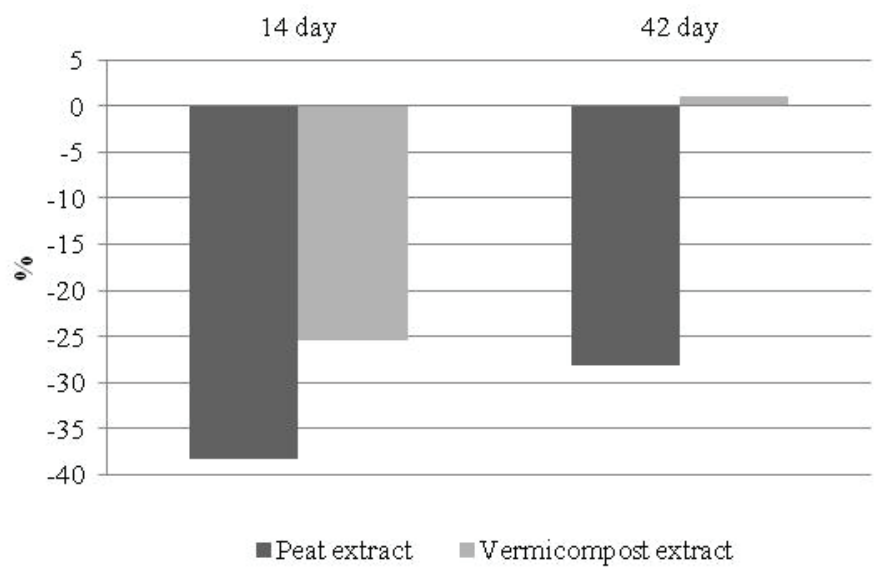

Fig. 6. The effect of peat preparation $\left(2.0 \mathrm{~mL}\right.$ per $\left.\mathrm{m}^{2}\right)$ and vermicompost preparation $\left(2.0 \mathrm{~mL}\right.$ per $\left.\mathrm{m}^{2}\right)$ on soil dehydrogenase activity ( $\%$ from control) in the onion experiment at the $14^{\text {th }}$ and $42^{\text {nd }}$ day after treatment.

was not purposeful. The treatment method bulblets soaking and after two times spraying was an inappropriate method because on average the decrease in total onion yield by $4 \%$ was detected. More significant decrease of yield was determined in the variant with cavited vermicompost.

\section{Conclusions}

1. The plant growth and response to different preparations depended on the plant species and its development stage. The effect of preparations decreases during plant development. The impact of peat or vermicompost preparation on soil biological activity depends not only on the concentration of preparation, but it is also influenced by the plant root growing features. A higher root density causes an increase in soil respiration intensity.

2. The decrease of onion yield in field conditions on average by $4 \%$ as a result of the use of humic preparations was observed.

\section{References}

1. Aon, M.A, Colaneri, A.C.(2001). II. Temporal and spatial evolution of enzymatic activities and physico-chemical properties in an agricultural soil. Applied Soil Ecology, 18(3), 255-270. Retrieved 10 September, 2013, from http:// dx.doi.org/10.1016/S0929-1393(01)00161-5. DOI: 10.1016/S0929-1393(01)00161-5.

2. Bloem, J., Schouten, A. J., Sorensen, S. J., Rutgers, M., Werf, A., Breure, A. M. (2005). Monitoring and evaluating soil quality. In Bloem J. et al. (Eds). Microbiological Methods for Assessing Soil Quality (pp. 23-36). Wallingford, CABI Publishing.
3. Brooke, P. (2001). The soil microbial biomass: concept, measurement and applications in soil ecosystem research. Microbes and Environments, 16, 131-140.

4. Burns, R. G., Nannipieri, P., Benedetti, A., Hopkins, D.W. (2005). Defining Soil Quality. In Bloem J. et al. (Eds). Microbiological Methods for Assessing Soil Quality (pp. 15-22). Wallingford, CABI Publishing.

5. Canellas, L. P., Olivare,s F. L., OkorokovaFaçanha, A. L. and Rocha, A. (2002). Humic Acids Isolated from Earthworm Compost Enhance Root Elongation, Lateral Root Emergence, and Plasma Membrane $\mathrm{H}^{+}$-ATPase Activity in Maize Roots. Plant Physiology, 130(4), 1951-1957.

6. Chen, W., Hoitink, A. J., Schmitthenner, A. F., Tuovinen, O. H. (1998). The role of microbial activity in suspension of damping-off caused by Pythium ultimum. Phytopathology, 78, 314-322.

7. Dobbss, L.B., Canellas, P.L., Lopes, O.F., Oliveira, A.N., Pres, A.N., Azevedo, M., Spaccini, R., Piccolo, A., Facanha, A. (2012). Bioactivity of chemically transformed humic matter from vermicompost on plant root growth. J.Agric.Food Chem., 58(6): 3681 - 3688.

8. Dubova, L., Alsina, I., Šteinberga, V. (2012). Comparison of Trichoderma $s p$. use efficiency on cucumbers and lettuce, Scientific Papers. Series B. Horticulture, 56, 101-104.

9. Fogarty, W. M., Ward, J. A. (1970). The influence of peat extract on Clostridium acetobutylicum. Plant and Soil, 32, 534-537.

10. Gamaley, A. V., Nadporozhskaya, M. A., Popov, A. I., Chertov, O. G., Kovsh, N. V., Gromova, O. A. (2001). Non-root nutrition with vermicompost extracts as the way of ecological optimisation. In 
Horst W.J.(Eds). Plant nutrition-Food security and sustainability of agro-ecosystems (pp. 862863). Kluwer Academic Publishers.

11. Kaimi, E., Mukaidami, T., Tamaki, M. (2007). Screening of Twelf Plant Species for Phytoremediation of Petroleum HydrocarbonContaminated Soil. Plant Production Science, 10, 211-218.

12. Kennedy, A.C., Stubbs, L.T., Schillinger, W.F. (2004). Soil and Crop Management Effects on Soil Microbiology. In Magdoff F. and Weil R.R. (Eds). Soil organic matter in Sustainable Agriculture (pp. 295-326). CRC Press.

13. Nawaz, N. and Gunasekaran, M. (1988). Effect of peat extract on the hydrolytic enzymes of Phanerochaete chrysosporium. Resources, Conservation and Recycling, 1, 197-205.

14. Parmar, N. and Dardarwal, K. R. (1999). Stimulation of nitrogen fixation and induction of flavonoid like compounds by rhizobacteria. Journal of Applied Microbiology, 86, 36-44.

15. Pell, M., Stenström, J. and Granhall, U. (2005). Soil respiration. In Bloem J. et al. (Eds). Microbiological Methods for Assessing Soil Quality (pp. 117-126). Wallingford, CABI Publishing.

16. Schiavon, M., Pizzeghello, D., Muscolo, A., Vaccaro, S., Francioso, O. and Nardi, S. (2010). High Molecular Size Humic Substances Enhance Phenylpropanoid Metabolism in Maize
(Zea mays L.). Journal of Chemical Ecology, 36, 662-669.

17. Sturz, A. V.and Christie, B. R. (2003). Beneficial microbial allelopathies in the root zone: the management of soil quality and plant disease with rhizobacteria. Soil and Tillage Research, 72, 107-123.

18. Tarnawski, M, Depta, K, Grejciun, D. and Szelepin, B. (2006). HPLC determination of phenolic acids and antioxidant activity in concentrated peat extract- a natural immunomodulator. Journal of Pharmaceutical and Biomedical Analysis, 41(1), 182-188.

19. Trevisan, S., Francioso, O., Quaggiott,i S.and Nardi, S. (2010). Humic substances biological activity at the plant-soil interface. Plant Signalling and Behaviour, 5(6), 635-643.

20. Warman, P. R. and AngLopez, M. J. (2010). Vermicompost derived from different feedstocks as a plant growth medium. Bioresource Technology, 101, 4479-4483.

21. Zaller, J. G. (2002). Foliar Spraying of Vermicompost extracts: Effects on Fruit Quality and Indications of late-Blight Suppression of Field-Grown Tomatoes. Biological Agriculture and Horticulture, 24, 165-180.

22. Zydlik, Z. and Zydlik, P. (2013). The effect of microbiological products on soil properties in the conditions of replant disease. ZemdirbysteAgriculture, 100(1), 19-24. 